\title{
VISUALISASI SUDUT PANDANG TOKOH UTAMA DENGAN PENERAPAN GRAYSCALE PADA PENYUTRADARAAN FILM FIKSI “DANILA”
}

\author{
Adina Iffah Izdihar \\ Agnes Widyasmoro \\ Alexandri Luthfi R \\ Jurusan Film \& Televisi, Fakultas Seni Media Rekam, Institut Seni Indonesia Yogyakarta \\ Jl. Parangtritis km. 6.5 Yogyakarta Telp. (0274) 381047
}

\begin{abstract}
The accountability of the artwork thesis Visualization of the Main Figures with Grayscale Application in the Directing of "Danila" Fiction Film aims to create audio-visual works with a cinematographic approach, point of view, and the application of grayscale as a symbol of the main character's emotional representation. The film "Danila" tells the life of a teenager who has psychological trauma that in this film, caused by a deep sense of loss over the death of her mother which was further aggravated by a change in the attitude of his father by becoming a workaholic who is rarely at home. Feelings of sadness, loss, and loneliness that are increasingly accumulating change Danila's character and way of dealing with life.

Cinematographic techniques with handheld camera movement, the use of camera angle $P O V$ that dominate, and the application of grayscale in Danila's visual point of view are intended to support the storyline, character subjectivity as teenagers who have psychological trauma, and as emotional representations when Danila experiences various kinds of daily life problems day.
\end{abstract}

Keywords: Directing, Film, Grayscale.

\begin{abstract}
ABSTRAK
Pertanggungjawaban skripsi penciptaan seni Visualisasi Sudut Pandang Tokoh Utama dengan Penerapan Grayscale pada Penyutradaraan Film Fiksi "Danila" bertujuan untuk menciptakan karya audio visual dengan pendekatan sinematografi, sudut pandang, dan penerapan grayscale sebagai simbol representasi emosi tokoh utama. Film "Danila" menceritakan kehidupan remaja yang memiliki trauma psikologis yang pada film ini, disebabkan karena rasa kehilangan mendalam atas kematian sang ibu yang kemudian diperparah dengan perubahan sikap sang ayah dengan menjadi seorang workaholic yang jarang berada di rumah. Rasa sedih, kehilangan, dan kesepian yang kian menumpuk merubah karakter dan cara Danila dalam menghadapi kehidupan.

Teknik sinematografi dengan pergerakan kamera handheld, penggunaan POV camera angle yang mendominasi, dan penerapan grayscale dalam visual sudut pandang Danila ditujukan untuk mendukung jalan cerita, subjektifitas tokoh sebagai remaja yang memiliki trauma psikologis, dan sebagai representasi emosi saat Danila mengalami berbagai macam problematika kehidupan sehari-hari.
\end{abstract}

Kata kunci: Penyutradaraan, Film, Grayscale

\section{Pendahuluan}

Keluarga merupakan barier atau garda terdepan yang memberikan pendidikan, perlindungan, kenyamanan, dukungan, dan hal hal positif lainnya terhadap perkembangan seorang individu. Keluarga merupakan awal dari lahirnya sosok individu yang baik maupun yang tidak baik. Pembinaan oleh keluarga dilakukan terus menerus sepanjang jalur kehidupan individu dalam keluarga tersebut. Pendidikan dari keluarga diberikan mulai dari budi pekerti, tata krama, agama, 
kehidupan sosial, dan lainnya untuk mencapai generasi yang berkualitas dengan penuh tanggungjawab, memiliki perilaku positif dan berdampak baik pada masyarakat, dan mampu menjadi penerus yang baik.

Proses pembentukan karakter dan perilaku tersebut memiliki unsur psikologis yang selalu diperhatikan. Setiap tahapan tumbuh kembang dan setiap ajaran atau didikan keluarga akan memunculkan respon individu yang berupa penerimaan, penolakan, keraguan, dan lainnya serta pengaruh lingkungan dan kelompok di luar keluarga seperti teman bermain, juga mempengaruhi proses tersebut. Inilah alasan mengapa orang tua harus berada disamping anak sampai anak tersebut cukup dewasa, mempunyai prinsip hidup yang tetap, dan benar-benar bisa membedakan yang baik dan yang buruk. Jika figur orang tua tiba-tiba menghilang ketika si anak belum cukup dewasa, akan ada dua hal yang mungkin terjadi: 1) anak tersebut mencari figur orang tua diluar rumah dan menyerap apapun dari lingkungan sekitar tanpa memfilter baik/buruknya; 2) anak tersebut akan cenderung tertutup dan membatasi kehidupan sosialnya pada lingkungan tertentu. (Lestari, 2013: 18-19).

Merujuk pada kondisi diatas, terwujudlah keinginan untuk membuat film mengenai kehidupan remaja yang kehilangan sosok kedua orangtuanya dan mengalami kemungkinan masalah psikologis ke dua; dimana anak akan cenderung tertutup dan membatasi kehidupan sosialnya pada lingkungan tertentu.

Film fiksi "Danila" akan menceritakan sisi psikologis yang dirasakan oleh seorang remaja bernama Danila yang ditinggal meninggal oleh ibu karena sakit kanker payudara, dan kehilangan sosok ayah yang berubah menjadi seorang workaholic sebagai pelampiasan rasa bersalah karena ketidakmampuan untuk membawa istrinya ke rumah sakit. Danila yang kehilangan sosok kedua orangtuanya mengalami perasaan kehilangan yang mendalam, kesepian dan apatis. Sifatnya pun berubah. Danila yang tadinya periang, mudah tertawa, ramah, sopan, berubah menjadi Danila yang pemurung, pendiam, pelit senyum, pesimis dan dingin. Semua yang dialami Danila; perubahan psikologis, perubahan sifat, hingga cara Danila ketika merespon/menghadapi suatu masalah, akan disajikan dengan bentuk visualisasi sudut pandang tokoh yang berwana hitam putih (grayscale). Visual grayscale ini diharapkan juga mampu untuk menguatkan tangga dramatik setiap konflik yang dialami Danila, sehingga emosi yang ingin disampaikan bisa diterima dengan baik oleh penonton.

\section{Pembahasan}

Film fiksi "Danila" merupakan film fiksi genre drama keluarga yang jelas berbeda dengan film fiksi genre drama keluarga lainnya, yang biasanya 
memunculkan kesan harmonis dalam sebuah hubungan keluarga. Peristiwa meninggalnya tokoh ibu mengakibatkan perubahan hubungan antara ayah dan anak, yang tadinya harmonis menjadi dingin. Dinginnya hubungan ayah dan anak ini kemudian direpresentasikan dengan dialog antara tokoh Ayah dan Danila yang cenderung formal dan baku, berbeda dengan dialog anatara Danila dan Dinda atau antara Danila dan Raka, begitu pula pada pengadeganannya. Pada sebuah film genre drama keluarga biasanya sangat mudah menemukan adegan skinship seperti adegan anak memeluk tokoh orangtua, orangtua menyiapkan kebutuhan tokoh anak, dan sebagainya untuk menunjukkan keharmonisan sebuah keluarga, namun pada tokoh Ayah dan Danila, adegan ini ditiadakan. Dari scene satu, tidak ada adegan skinship sama sekali sebagai salah satu faktor untuk memvisualisasikan kekakuan hubungan antara Ayah dan Danila remaja, hingga akhirnya pada scene

30 terdapat adegan skinship dengan adegan Ayah memeluk Danila saat meminta maaf dan menautkan jari kelingking sebagai simbol perjanjian bahwa Ayah akan berubah. Adegan skinship antara Ayah dan Danila lainnya hanya terdapat pada scene flashback Danila kecil saat ibu masih hidup, dengan adegan Ayah dan Danila kecil menari bersama lalu pada adegan Ayah mengusap rambut dan memeluk Danila kecil untuk menenangkan Danila kecil yang sedang menangis saat melihat jenazah ibu.

\section{Desain Produksi}

$\begin{array}{ll}\text { Kategori } & \text { : Cerita. } \\ \text { Media } & \text { : Digital } \\ \text { Judul } & \text { : Danila. } \\ \text { Format } & \text { : Film Fiksi. } \\ \text { Temre } & \text { : Drama Keluarga. } \\ \text { Target Audien } & \text { : Kehidupan remaja. } \\ & \text { dewasa usia 50 tahun } \\ & \text { dengan kelas sosial } \\ & \text { dari A+ hingga kelas } \\ & \text { C. } \\ \text { Kategori Produksi } & : \text { Non studio. } \\ \text { Durasi } & : 30 \text { menit. } \\ \text { Premis } & : \text { Kesepian yang } \\ & \text { mendalam akibat } \\ & \text { kehilangan sosok } \\ & \text { penting dalam hidup. }\end{array}$

\section{Sinopsis}

Danila (17) adalah seorang gadis remaja yang sedang menempuh pendidikan di bangku SMA kelas 2. Danila berasal dari keluarga kecil yang hanya terdiri dari Danila dan Ayah karena Ibu telah meninggal akibat penyakit yang dideritanya. Masalah mulai muncul ketika ayah Danila, Riyadi (40) merasa ialah yang membunuh istrinya atas ketidakmampuannya untuk membawa ibu Danila, Kinanti (35) ke rumah sakit. Sejak peninggalan Kinanti, Riyadi bekerja mati matian untuk memenuhi kebutuhan dan menghindari kejadian yang sama pada Danila, namun Riyadi lupa, bahwa selain materi, Danila juga butuh kasih sayang. 
Kematian sang Ibu dan hilangnya sosok Ayah membuat Danila mengalami trauma psikologis dan merubahnya menjadi anak yang pemurung, tertutup dan apatis dalam menghadapi lingkungan. Sifat dan kehidupan yang Dinda miliki berbeda 180 derajat dibanding Danila, namun Dinda selalu ada disaat Danila butuh. Teman teman sekolah dan guru beberapa kali memergoki Danila berbicara dengan Dinda yang tidak terlihat, dan itu membuat mereka semakin menjauhi Danila. Pada saat pengambilan rapot, Ibu Guru memberitahu Ayah mengenai keanehan Danila tersebut. Ayah yang awalnya tidak percaya menjadi percaya saat Ayah melihat Danila berbicara dan tertawa sendiri di kamar. Ayah yang merasa menyesal karena telah menelantarkan Danila akhirnya meminta maaf dan berjanji meluangkan waktu lebih banyak untuk Danila.

\section{Proses Produksi}

Pembuatan karya film fiksi "Danila" melalui beberapa tahap umum yaitu praproduksi, produksi, dan pasca-produksi dengan rincian kegiatan sebagai berikut :

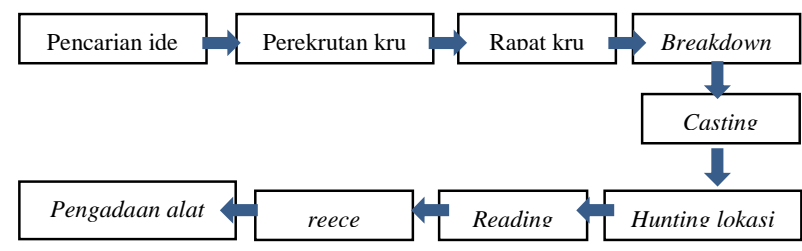

1. Pra Produksi

a. Pencarian ide

Pencarian ide cerita film fiksi "Danila" berawal dari ketertarikan pada kekuatan warna dan fenomena kehidupan para remaja kota besar di Indonesia.

\section{b. Merekrut Kru}

Proses produksi sebuah film tidak akan terlepas dari peranan para kru. Pembentukan tim produksi "Danila" dimulai dari pencarian tim produksi, $D O P$, gaffer, tim audio dan tim artistik. Teknis perekrutan kru dilakukan dengan menghubungi yang bersangkutan via sosial media dan melalui relasi teman perfilman luar kampus. Setelah seluruh tim terkumpul, dimulailah penentuan tanggal produksi. Awalnya, produksi akan dilaksanakan pada tanggal 12-16 November 2018. Namun karena adanya beberapa pertimbangan, produksi dipercepat menjadi tanggal 11-14 November 2018.

c. Rapat Kru

Skenario dengan judul "Danila" yang telah selesai disusun oleh penulis naskah kemudian dijadikan pedoman untuk memulai proses produksi. Sebelum memulai produksi, dibutuhkan rapat produksi untuk memperjelas apa-apa saja yang harus dipersiapkan. Rapat perdana dilakukan pada tanggal 28

September 2018, dengan agenda perkenalan kru, divisi yang dipegang, dan penjelasan konsep film secara menyeluruh. Setelah rapat perdana, terdapat beberapa rapat lainnya, seperti rapat antara sutradara dengan divisi yang bersangkutan, PPM (pra production meeting) bersama seluruh kru 
dengan agenda pembahasan mengenai progress yang sudah dibuat, dan yang terakhir script conference meeting dengan agenda pembahasan adegan yang ditambahkan diluar naskah.

d. Breakdown Naskah, Menyusun Jadwal Produksi, dan Budgeting

Setelah rapat perdana, setiap divisi mulai membuat breakdown naskah. Dari breakdown ini, kemudian disusun budgeting (rencana anggaran dana) yang menjadi acuan produser untuk mengelola biaya produksi secara maksimal. Selain membuat breakdown naskah dan budgeting produksi, disusun pula jadwal produksi. Jadwal produksi disusun oleh asisten sutradara satu dan produser, sehingga kru memiliki target dalam menyelesaikan tugasnya.

\section{e. Casting Talent}

Kortel (koordinator talent) bersama sutradara mulai bergerak mencari pemeran karakter tokoh dalam film "Danila". Jenis casting yang diterapkan pada pemilihan pemain film fiksi "Danila" adalah jenis casting by ability dan casting to type. Casting by ability merupakan pemilihan pemain berdasarkan kemampuannya beradaptasi menjadi tokoh dalam penceritaan berdasarkan tiga dimensinya. Sementara casting to type merupakan pemilihan pemain berdasarkan kedekatan fisik karakter di cerita seperti tinggi badan, berat badan, dan bentuk tubuh. Pencarian pemain diutamakan pada tokoh Ayah dan Danila, baru kemudian menyusul tokoh Ibu, Danila kecil, Raka, Ibu Guru, dan teman sekolah Danila.

\section{f. Hunting Lokasi}

Tim lokasi bersama sutradara dan produser mulai mencari lokasi yang akan dijadikan set pada film "Danila". Total keseluruhan set lokasi pada naskah ada lima, yaitu: 1) lokasi rumah Danila kecil berada di Jalan Geneng, Sewon, 2) lokasi rumah Danila remaja berada di Pogung Lor, Ringroad Utara Yogyakarta, 3) lokasi SMA berada di SMA 11

Yogyakarta. Sementara dua lokasi outdoor, yaitu taman kota, berada di Taman Kota Denggung, Sleman, dan camping ground berada di Waduk Sermo, Kulonprogo. Setelah menentukan lokasi yang diinginkan, location manager bersama asisten mulai bergerak mengurus kerjasama dan perizinan, dibantu oleh produser dan line produser. Setelah masalah perizinan selesai, tim segera mensurvei tempat untuk melakukan penyesuaian dengan hasil breakdown naskah yang sudah dibuat.

\section{g. Reading}

Talent membaca naskah beberapa kali hingga hafal, kemudian berlatih adegan dan blocking. Reading talent dilakukan beberapa kali bagi pemeran Danila dan Dinda, untuk membantu mempercepat penghafalan dialog karena mereka bukan berasal dari dunia teater. Sementara untuk pemeran Ayah dan Danila kecil, reading 
Adina Iffah Izdihar, Agnes Widyasmoro, Alexandri Luthfi R, Latief Rakhman Hakim

Visualisasi Sudut Pandang Tokoh Utama dengan Penerapan Grayscale pada Penyutradaraan Film Fiksi "DANILA"

hanya dilakukan satu kali, karena mereka sudah biasa berakting.

h. Recce

Recce pertama kali dilakukan pada tanggal 5 November 2018, lalu dilanjut pada tanggal 6 dan 9 November 2018 bersama perwakilan anggota dari setiap divisi. Dari recce dapat dilihat framing dan blocking yang akan dilakukan saat shooting. Karena padatnya jadwal, recce dilakukan tanpa pemain, namun tetap menggunakan pemain pengganti untuk memeragakan blocking adegan. Lokasi pelaksanaan recce dilaksanakan di semua set yang nantinya akan digunakan shooting. Proses ini menghasilkan improvisasi berupa penambahan dan pengurangan scene untuk memaksimalkan cerita.

\section{i. Pengadaan Alat}

Setelah recce, technical director (yang kemudian disingkat TD) bersama chief tiap divisi membuat breakdown alat apa saja yang dibutuhkan, lalu mencari tempat penyewaan alat dengan harga yang paling terjangkau. TD juga mengatur jadwal pengambilan dan pengembalian alat sebagai acuan driver untuk stand by di kampus.

\section{Produksi}

Tahap produksi merupakan proses pengambilan gambar dan penerapan dari apa yang sudah dipersiapkan di tahap pra-produksi. Proses produksi film fiksi "Danila" dimulai dari tanggal 11 - 14 November 2018.

\section{Pasca Produksi}

a. Preview hasil shooting
Preview hasil shooting pada tahap pasca-produksi bertujuan untuk mengamati dan memilah lagi gambar yang akan dipakai atau tidak. Pada proses ini baru diketahui ada beberapa gambar yang memiliki kecacatan dan tidak ada pilihan lain sehingga harus diretake. Sementara gambar lainnya aman, editor kemudian lanjut ke proses editing offline.

\section{b. Editing Offline}

Proses editing offline merupakan proses pemotongan, penyusunan gambar dari berbagai angle, dan penyesuaian durasi oleh editor dan sutradara. Selain itu, editor juga memasukan audio guide untuk memudahkan saat sound designer mengedit kebutuhan audio film.

\section{c. Audio Mixing}

Audio mixing merupakan proses penyusunan dan penggabungan data suara maupun ilustrasi musik lainnya dengan hasil editing offline. Proses ini meliputi volume suara, perpindahan musik dan sebagainya agar terdengar harmonis.

\section{d. Editing Online}

Editing online merupakan proses pengerjaan color correction, grading, penambahan grafis dan credit title. Proses ini adalah proses terpenting karena disinilah output warna film "Danila" ditentukan. Persentase penggunaan warna grayscale dan colourful bisa dibilang seimbang, karena warna grayscale hanya diterapkan pada angle camera POV dan subjektif tokoh 
Danila, sementara penerapan warna pada angle camera tokoh lainnya akan tetap colourful. Sutradara dan colourist berdiskusi untuk setiap shot dan warna pada film "Danila" agar dapat menyampaikan keadaan psikologis dan perkembangan emosi Danila sepanjang film.

\section{e. Packaging}

Packaging merupakan proses akhir sebuah karya yang dapat dinikmati oleh penonton. Hasil final yang telah dikerjakan selama proses editing kemudian ditransfer dalam bentuk dvd yang dikemas dalam bentuk yang menarik dengan kelengkapan desain cover, poster, katalog, undangan, dll.

\section{Pembahasan Karya}

Penerapan gambar grayscale pada visualisasi sudut pandang tokoh utama film "Danila" dilakukan dengan mengaplikasikan angle camera POV dan subjektif. Penggunaan angle camera ini untuk memberikan sedikit demi sedikit informasi kepada penonton mengenai trauma psikologis yang dialami oleh Danila. Informasi ini diberikan secara sedikit demi sedikit dan mungkin akan memberikan persepsi lain terhadap film ini hingga sampai di akhir cerita, terkuaklah kebenaran mengenai penyakit Danila yang didukung melalui aspek sinematografi, alur cerita, sudut pandang tokoh, simbol dan transisi warna pada film.
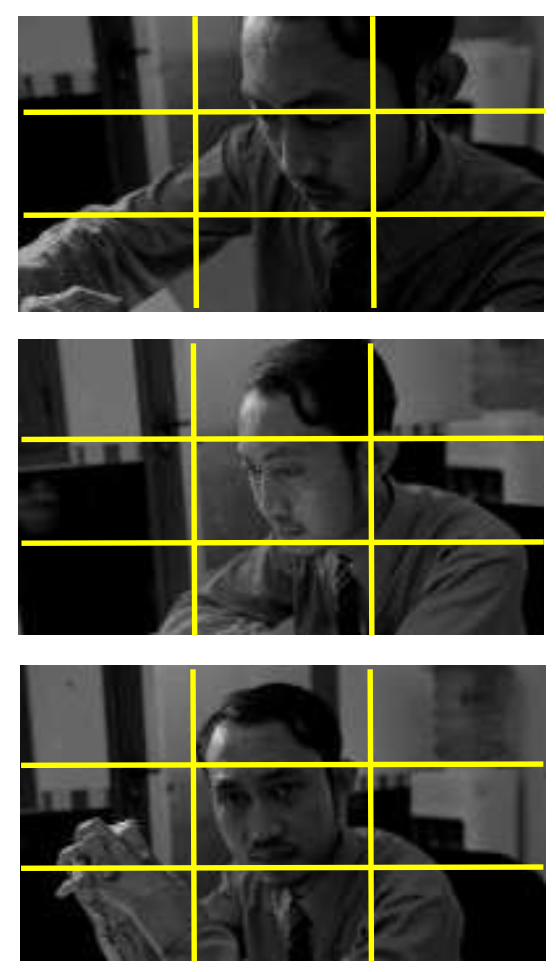

Danila memandang Ayah yang tidak berbicara sama sekali. Tidak lama, Ayah menanyakan perihal sekolah Danila dan menyemangatinya untuk berlajar. Lalu Riyadi menutup percakapan dengan berkata mereka harus berangkat terpisah karena ia ada urusan pekerjaan.

Berikut merupakan salah satu contoh pengaplikasian aspek - aspek diatas pada film "Danila".

\section{Analisis:}

Komposisi yang digunakan adalah komposisi dinamis dan simetris dengan acuan garis titik imajiner rules of third dengan shot size close up dan camera angle $P O V$ sebagai visualisasi cara Danila melihat ayah. Penggunaan warna grayscale dengan intensitas gelap - terang - gelap yang cukup kuat ditujukan untuk mewakili perasaan Danila yang merasa sedih, kesal, 
Adina Iffah Izdihar, Agnes Widyasmoro, Alexandri Luthfi R, Latief Rakhman Hakim

Visualisasi Sudut Pandang Tokoh Utama dengan Penerapan Grayscale pada Penyutradaraan Film Fiksi "DANILA"

sekaligus terkucilkan karena ketidak dekatannya dengan sang ayah.

Pada shot 1, intensitas grayscale berwarna gelap karena Riyadi sama sekali tidak menyapa Danila saat Danila memasuki ruang makan. Kemudian intensitas grayscale berubah menjadi lebih terang karena Danila merasa sedikit senang saat Riyadi menunjukkan perhatiannya dengan menanyakan kondisi pembelajaran Danila di sekolah. Lalu pada shot terakhir saat Riyadi menyudahi percakapan, Danila merasa kembali kecewa karena kehangatan Riyadi kembali menghilang, sehingga intensitas grayscale berubah menjadi lebih gelap namun tidak segelap shot 1.

Ayah memasuki kamar Danila, duduk ditepian kasur. Ayah memandang Danila dengan tatapan bersalah lalu tiba - tiba memeluk Danila dan menangis.
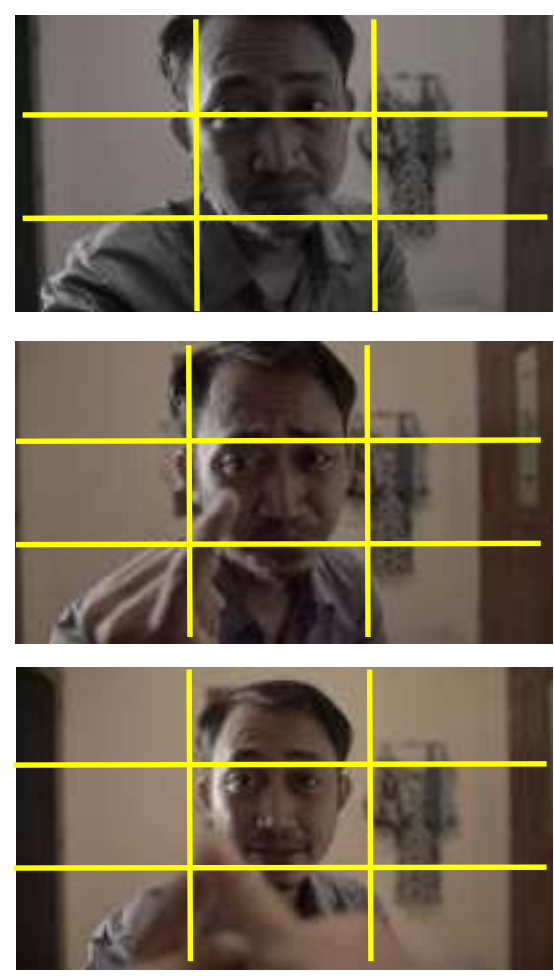

Analisis:

Penerapan komposisi dinamis dimana subjek terletak tepat di titik garis imajiner rules of third yang dikombinasikan dengan camera angle POV dan shot size close up gambar diawal dengan intensitas grayscale yang cukup pekat karena Danila masih merasa kesal pada ayah secara perlahan perasaan kesal ini berubah setelah ayah meminta maaf dan berjanji akan mulai meluangkan waktu untuk Danila. Pada momen inilah Danila mulai kembali merasakan kasih sayang ayahnya yang kemudian direpresentasikan melalui intensitas grayscale yang perlahan memudar dan berubah menjadi warna colourful.

\section{Kesimpulan}

Sudut pandang tokoh utama adalah cara melihat tokoh utama suatu film dalam melihat kehidupan sehari hari, baik dengan atau tanpa masalah. Lewat visualisasi sudut pandang ini, beberapa informasi akan terbatasi karena informasi tersebut hanya dialami oleh satu tokoh saja dan tentunya akan berbeda dengan apa yang dialami tokoh lain. Kamera bisa jadi tidak lepas dari tokoh utama, karena itulah yang dibutuhkan untuk mengimplementasikan konsep tersebut. Penerapan grayscale pada visualisasi sudut pandang tokoh utama akan menambah variasi lain dalam penceritaan.

Visualisasi sudut pandang tokoh utama dengan penerapan grayscale sebagai 
simbol representasi terhadap kondisi psikologi Danila di kehidupan sehari hari sangat mampu membantu penyampaian visual storytelling yang dikonsepkan. Perlu diingat bahwa tonal warna grayscale tidak pernah lepas dari lightness atau intensitas cahaya, sehingga ketika Danila mengalami suatu masalah yang cukup berat, maka intensitas warna grayscale akan semakin pekat dan sebaliknya, ketika masalah yang dialami ringan, intensitas warna grayscale akan semakin memudar. Menuju akhir film pada scene 22, ketika Riyadi dan Danila selesai bertengkar, warna grayscale Riyadi terlihat sangat pekat dimata Danila karena ia sangat membenci ayahnya. Di akhir film pada scene 31, perlahan warna grayscale Riyadi semakin memudar dan berubah menjadi berwarna. Hal ini dikarenakan Danila mendapatkan afeksi dari ayahnya yang berupa kasih sayang. Kasih sayang inilah yang meluluhkan rasa benci, kesepian, dan kehilangan Danila sehingga akhirnya Danila bisa kembali melihat dunia penuh warna.

\section{Daftar Pustaka}

Pratista, Himawan. Memahami Film. Yogyakarta: Homerian Pustaka, 2008.

Lestari, Sri. Psikologi Keluarga: Penanaman Nilai dan Penangan Konflik dalam Keluarga. Jakarta: Prenada Media Grup, 2013.

Budiman, Kris. Semiotika Visual: Konsep, Isu dan Problem Ikonisitas. Yogyakarta: Jalasutra Anggota IKAPI, 2011.

Wright, Angela. Color Psychology (the "Colour Affects" system). UK: OKI Printing Solutions, 2002. 